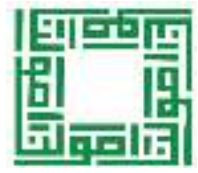

\title{
KEDUDUKAN AKAL DALAM ISLAM: PERDEBATAN ANTARA MAZHAB RASIONAL DAN TRADISIONAL ISLAM
}

\author{
Reynaldi Adi Surya ${ }^{1}$ \\ ${ }^{1}$ SMK Voctech 1 Tangerang \\ Kota Tangerang, Banten, Indonesia \\ adisuryareynaldi@gmail.com
}

Abstrak:

Akal dalam kehidupan manusia memiliki arti yang sangat penting dan vital. Tidak salah jika dikatakan bahwa yang membuat manusia bertahan hidup dan mengembangkan budaya serta peradaban yang menakjubkan. Dalam Islam akal juga diakui sebagai salah satu karya cipta Allah yang luar biasa, namun dalam tradisi intelektual Islam, para ulama dan cendekiawan memperdebakan mengenai apa itu akal dan sejauh mana peran akal dalam masalah keagamaan. Para filosof Muslim dan fuqaha ahl ra'y membela akal sebagai sumber pengetahuan dan rujukan dalam kehidupan dan masalah agama, namun para ulama ahli hadīs dan yang memegang tradisi fiqh literal menganggap peran akal sangat terbatas dalam masalah agama, bahkan ada yang berpandangan tidak diizinkan akal bermain dalam ranah agama. Hingga detik ini, perdebatan klasik mengenai akal dan kemampuan rasional manusia masih terus diperdebatkan khususnya dalam bidang agama. Penulis akan menggambarkan kembali perdebatan itu secara singkat dalam artikel ini.

Kata Kunci: Akal, failasuf, fuqaha, ahl ra'y, ahl ḥadīts, tradisionaisme, rasionalisme

\begin{abstract}
:
Reason has an important and vital meaning in human life. It's not wrong if it says about what makes human survive and expand their culture along with their amazing civilization. in moslem, reason also recognized as one of god's greatest creation, but in moslem's intellectual tradition, scholars and highbrows argue about what mind actually means and the extent role of reason spiritually. Moslem philosophers and fuqaha ahl ra'y stick up with reason as the source of knowledge and references within life and religions problem, however hadith expert and the one who stick to literal tradition assume that mind's role is very limited in religions problem, some even think that reason is not permitted to play in religion realm. Up until this moment, classic debate about reason and human rational capability are still being debated, especially in religion realm. writer tried as much as possible to redescribe those controversy shortly in this article.
\end{abstract}

keywords: Reason, philosopher, fuqaha, ahl ra'y, ahl hadīs, traditionalism, rationalism 


\section{Pendahuluan}

Dalam nomenklatur Islam betapa banyak riwayat dan kisah yang telah ditulis mengenai perdebatan intelektual dan gagasan-gagasan segar yang sangat bermanfaat dan kaya akan wawasan. Ini menunjukan bahwa tardisi ilmiah Islam sangat memiliki iklim yang liberal, dimana pada masanya perbedaan pandangan dan penafsiran agama tidak selalu harus berujung pertumpahan darah. Telah banyak teori dan juga pemikiran ulama Islam klasik yang dapat kita nikmati saat ini, baik tema perdebatan itu mengenai soal-soal falsafat, fiqh, astronomi, ilmu hadits, tafsir Qur'an, hingga masalah linguistik dapat kita temui.

Jika kita melacak awal sejarah perkembangan intelektual Islam, tentu suatu yang menakjubkan bahwa dalam rentang 200 tahun, para ulama Islam yang pada awalnya membahas soal-soal sederhana lalu berkembang ke dalam pembahasan yang rumit dan falsafi. Perkembangan pemikiran dalam masyarakat Arab yang lampau, menurut pendapat Nurcholish Madjid, karena Islam itu sendiri yang mendorong agar umatnya menuntut ilmu dan mengembangkan wawasan. Selain itu hadits Nabi yang mendorong agar umatnya berani berijtihad, ${ }^{1}$ membuat pintu ilmiah dalam masyarakat Islam semakin terbuka. ${ }^{2}$

Seiring dengan berkembangnya agama Islam dan munculnya polemik mengenai penafsiran Al-Qur'an dan hadits dalam menjawab persoalan yang berkembang, muncullah berbagai pandangan yang beragam baik dalam masalah aqidah, fiqh atau masalah penafsiran Al-Qur'an. Secara garis besar, muncul kelompok yang mengandalkan inovasi dalam menyelesaikan masalah dengan menggunakan kemampuan akalnya dan mengqiyaskan problem-problem baru, kelompok ini disebut sebagai ahl ra'yu (dari ra'yun jamaknya ara ' $u$ yang berarti pendapat pikiran) atau kelompok rasionalis (tokoh terkenalnya adalah Imam Abu Hanifah). ${ }^{3}$ Disisi lain muncul kelompok yang berpegang teguh pada teks literal kitab suci dan riwayat dari nabi dan para pendahulu dalam menjawab masalah-masalah keagamaan dan menahan diri dari masalah yang rumit dan memacu perdebatan, kelompok ini adalah kelompok ahl hadīs atau tradisionalis. ${ }^{4}$ Sedangkan dalam terminologi yang populer di mazhab syī'ah, kelompok rasional dinamakan ușūli dan kelompok tradisional disebut golongan

${ }^{1}$ Hadis yang dimaksud adalah hadis yang diriwayatkan oleh 'Amru bin Al-'Aash: Bahwasannya Rasulullah shallallaahu 'alaihi wa sallam bersabda: "Apabila seorang hakim menghukumi satu perkara, lalu berijtihad dan benar, baginya dua pahala. Dan apabila ia menghukumi satu perkara, lalu berijtihad dan keliru, baginya satu pahala" hadits ini diriwayatkan oleh Imam Al-Bukhari dan Imam Muslim.

${ }^{2}$ Nurcholish Madjid, Khazanah Intelektual Islam (Jakarta: Bulan Bintang, 1984), 81.

3 Mohammad Takdir, "Membumikan Fiqh Antroposentris: Paradigma Baru Pengembangan Hukum Islam yang Progresif,” Jurnal Ahkam 7, no. 1 (2019): 98.

4 Sulaiman Abdullah, Dinamika Qiyas dalam Pembaharuan Hukum Islam (Jakarta: Pedoman Ilmu Jaya, 1996), 18-19. 
$a k h b \bar{a} r \bar{r} .{ }^{5}$ Kedua kelompok pemikiran tersebut (rasionalis dan tradisionalis) kemudian berkembang lebih jauh dan membentuk suatu mazhab yang mapan dan dengan metode yang baku.

Munculnya kedua mazhab tersebut tak lain karena kedua kelompok tersebut berbeda pandangan dalam menempatkan posisi akal dan berbeda porsi penggunaan akal. Hingga akhirnya mendorong perdebatan yang lebih intensif mengenai akal dalam tradisi intelektual Islam. Pertanyaan seputar apa hakikat akal? Apa fungsi akal? Apakah akal bisa mencapai kebenaran? Dan seberapa jauh akal itu berperan dalam kehidupan manusia, khususnya dalam hal agama, membuat diskusi menjadi menjadi mengarah pada pembahasan falsafi.

Golongan tradisionalis adalah kelompok yang skeptis terhadap akal. Dalam menjawab masalah sehari-hari, mereka mencukupkan diri pada nusus dan asar dan menolak penggunaan akal. Mereka berpendapat bahwa apa yang diturunkan oleh Allah dan rasulnya sudah sedemikian sempurna sehingga tidak dibutuhkan inovasi. Áyat yang menjadi legitimasi kaum tradisionalis adalah surah Al Maidah ayat 3, yang berbunyi: "Pada hari ini, telah Kusempurnakan agama kalian untuk kalian, dan telah Kucukupkan Nikmat-Ku bagi kalian, dan telah Kuridhai Islam sebagai agama kalian.”

Golongan rasionalis (baik itu filusuf, mutakallimūn, atau fuqaha) menolak argumentasi yang terlalu kaku dan dogmatis dari kelompok tradisionalis. Kelompok ini berpendapatbahwa kedudukan akal sangat tinggi dan Allah sendiri menganugrahkan akal dan mencela orang-orang yang menolak menggunakan akalnya, sebagaimana firman Allah dalam surah Al-A'raf ayat 179 yang berbunyi: "Dan sesungguhnya Kami jadikan (isi neraka Jahannam) kebanyakan dari jin dan manusia, mereka mempunyai qalbu, ${ }^{6}$ tetapi tidak dipergunakannya untuk memahami (ayat-ayat Allah).”

Perdebatan ini kemudian memacu suatu polemik yang bersifat akademis. Pembahasan mengenai akal menjadi hal menarik, sebab perselisihan antara kelompok rasionalis dan tradisionalis telah merembet keberbagai tema-tema keislaman seperti falsafat, kalam (aqidah), dan juga fiqh yang membuat disiplin ilmu keislaman tersebut menjadi hidup dan berkembang.

\section{Akal dalam Tinjauan Al-Qur'an}

Tidak ada harta berharga yang dimiliki oleh manusia selain akal budi . Akal budi yang menggerakan dan mendorong manusia melahirkan mahakarya berupa kebudayaan dan peradaban. Berkat akal budi juga manusia bisa bertahan hidup mengarungi bahtera kehidupan dunia. Tanpa akal dan kemampuan

${ }^{5}$ Murtaḍa Muțahhari dan Muhammad Baqir Șadr, Pengantar Ushul Fiqh dan Ushul Fiqh Perbandingan, terj. Satrio Pinandito dan Ahsin Muhammad (Jakarta: Pustaka Hidayah, 1993), 153.

${ }^{6}$ Kata qalb dipahami juga sebagai akal. Akan dibahas dibagian selanjutnya. 
berpikirnya, mustahil manusia bisa beradaptasi dengan lingkungan atau menciptakan perkakas benda yang ia gunakan.

Dalam istilah 'ilm Manțiq (logika) manusia adalah hewan yang berpikir, dengan kata lain yang menjadi cirikhas sekaligus pembeda antara manusia dengan makhluk lainnya adalah kemampuannya dalam berpikir dan mengolah serta merealisasikan pemikirannya. Memang menakjubkan jika direnungkan, bahwa segala bentuk-bentuk kebudayaan, tradisi, peralatan tekhnologi, bahkan sistem sosial merupakan hasil dari suatu proses berpikir manusia.

Kata akal bersumber dari bahasa Arab al-'aql. Harun Nasution menjelaskan bahwa kata akal memiliki banyak arti dalam bahasa Arab. Akal bisa bermakna menahan yang berarti menahan diri dari hawa nafsu, namun akal juga bisa bermakna kebijaksanaan (al-nuha). Muhammad Abduh sendiri berpendapat bahwa akal adalah salah satu bentuk karunia dan hidayah dari Allah pada manusia. ${ }^{7}$ Dalam al-Qur'an, banyak kata yang menyinggung soal akal, berikut contohnya:

"Seburuk-buruk binatang pada Allah adalah yang tuli, bisu, dan tidak mempergunakan Akal (Ya 'qilun)" (QS. al-Anfāl: 22)

"Musa berkata: "Tuhan yang menguasai timur dan barat dan apa yang ada di antara keduanya: (Itulah Tuhanmu) jika kamu mempergunakan akal (Ta'qilun)" (QS. al-Syu'arā: 28)

"Makanlah dan gembalakanlah binatang-binatangmu. Sesungguhnya pada yang demikian itu, terdapat tanda-tanda kekuasaan Allah bagi orang-orang yang berakal (ūlin Nuhā)". (QS. Țāhā: 54)

"Allah menyediakan bagi mereka azab yang keras, maka bertakwalah kepada Allah hai orang-orang yang mempunyai akal (Ulil al-Bāb; (yaitu) orangorang yang beriman. Sesungguhnya Allah telah menurunkan peringatan kepadamu". (QS. al- Ṭalāq: 10)

Melihat ayat-ayat diatas,poin terpenting adalah, dalam al-Qur'an akal mempunyai konotasi yang positif, dimana akal sebagai tolak ukur dan penimbang kebenaran dan kesalahan. Dalam surah al-Anfāl ayat 22, Allah malah menyamakan orang yang tidak menggunakan akalnya dengan binatang. al-Qur'an menggambarkan fungsi akal dengan sangat jelas dan menegaskan bahwa orang-orang yang mencapai ulil al-bāb adalah orang-orang bertakwa dan memiliki kesadaran sempurna sehingga ia dapat beriman pada Tuhan.

Dalam tradisi falsafat, teologi ( $\mathrm{kalām}$ ), atau mistisisme Islam, letak akal bukanlah di otak atau kepala seperti yang diperkirakan banyak orang saat ini. Akal dalam tradisi Islam adalah bagian dari jiwa manusia dan letaknya di

${ }^{7}$ Aan Rukmana, "Kedudukan Akal dalam al-Qur'an dan al-Hadis," Jurnal Mumtāz 1, no. 1 (2017): 25. 
jantung (atau hati) yang berpusat di dada. Dalam pandangan Islam (khususnya falsafat) antara akal ( $a l$ - 'aql) dengan jiwa (al-rūh) memiliki kedekatan bagai dua sisi dalam satu realitas, sehingga akal itu sendiri adalah realitas metafisik yang berada dalam diri manusia. ${ }^{8}$

Istilah al-'aql juga bersinonim dengan al-qalb, dalam tradisi sufisme alqalb dipahami sebagai hati yang memiliki daya intuitif yang berbeda dengan $a l$ 'aql yang berfungsi sebagai daya intelek. Namun dalam al-Qur'an kalbu atau $a l$ qalb memiliki fungsi yang sama dengan $a l$ - 'aql, yaitu untuk memahami suatu objek yang bersifat fisik (bukan kabar ghaib yang ditangkap melalui metode intuitif).

"Dan sesungguhnya Kami jadikan (isi neraka Jahannam) kebanyakan dari jin dan manusia, mereka mempunyai kalbu, tetapi tidak dipergunakannya untuk memahami (ayat-ayat Allah) dan mereka mempunyai mata (tetapi) tidak dipergunakannya untuk melihat (tandatanda kekuasaan Allah), dan mereka mempunyai telinga (tetapi) tidak dipergunakannya untuk mendengar (ayat-ayat Allah)." (QS. Al-A'rāf: 179)

Dari ayat diatas jelas bahwa kalbu, mata, dan telinga adalah alat untuk memahami ayat-ayat (tanda-tanda) kebesaran Allah. Dengan demikian, maka alqalb dalam Al-Qur'an berfungsi sebagai daya intelek yang sama dengan fungsi akal. ${ }^{9}$ Menurut Toshihiko Izutzu, 'aql di masa Arab jahiliyah diartikan sebagai practical intellegene atau intelektual praktis. Dimana ssalah satu sifat akal adalah dapat menyelesaikan problem-problem praktis yang dihadapi dalam kehidupan. Kebijaksanaan untuk menyelesaikan masalah dan membebaskan diri dari suatu bahaya adalah salah satu fungsi 'aql menurut masyarakat Arab jahiliyah, sehingga kedudukan akal dimasa itu amat dihormati.

\section{Akal dalam Pandangan Mazhab Rasional}

Di dalam agama Islam, peran akal dinilai mendapat kedudukan yang tinggi sebagai penjaga wahyu. Dalam memandang kedudukan akal, mazhab rasional adalah salah satu kelompok dalam Islam yang menganggap bahwa akal adalah alat yang kokoh dalam mencari kebenaran dan sumber epistemologis untuk mendapatkan pengetahuan. Akal mendapat posisi yang istimewa karena Allah sendiri yang menganugrahkannya kepada manusia sebagai jalan kepadanya, bahkan dalam sebuah Hadits Masyhur dari Rasulullah SAW tentang keutamaan akal, Rasulullah bersabda: "Tidak ada Agama bagi orang yang tidak memiliki Akal"

\footnotetext{
${ }^{8}$ Harun Nasution, Akal dan Wahyu dalam Islam (Jakarta: UI Press, 2011), 6.

${ }^{9}$ M. Arif Setiawan dan Melvien Zainul Asyiqien, "Urgensi Akal Menurut Al Qur'an dan Implikasinya dalam Mencapai Tujuan Pendidikan Islam,” Jurnal Intelektual 9, no. 1 (2019): 41.
} 
Dari Mūsa bin Ja'far (al-Kāzim) : “ Sesungguhnya Allah menurunkan 2 hujjah, yaitu hujjah lahir dan hujjah batin. Hujjah lahir adalah para rasul, nabi dan imam, dan hujjah batin adalah akal".

Rasulallah bersabda: "Yang pertama kali diciptakan Allah adalah akal, kemudian Allah berfirman, "Datanglah kemari!" maka akal itupun datang. Kemudian Allah berfirman kepadanya, "Pergilah" maka akal itu pergi. Allah berfirman: "Demi kemuliaan dan keagunganku, tidaklah kuciptakan makhluk yang lebih mulia bagiku daripadakamu. Dengan engkau Aku mengambil dan dengan engkau Aku memberi. Dengan engkau Aku mengganjar pahala dan dengan engkau Aku menghukum.

Rasulallah bersabda: Aku bertanya kepada Jibril, "apakah kepemimpinan itu? " Jibril menjawab "akal"10

Merujuk dalil nash tersebut, akal dalam Islam mendapat kedudukan yang tinggi dan Allah mennggikan derajat orang-orang yang menggunakan akalnya untuk menuntut ilmu. Riwayat diatas menunjukan bahwa akal adalah makhluk ciptaan Allah yang mampu menunjukan kebenaran dan kebatilan. Dari riwayat inilah para failasuf dan juga mutakallimun sangat menghargai dan menjadikan akal sebagai sumber pengetahuan yang terpercaya.

\section{Akal Menurut Para Filusuf}

Dalam pandangan para failasuf, akal bukan hanya sekedar alat untuk mendapat pengetahuan, namun para failasuf meyakini bahwa akal merupakan wujud metafisik yang memiliki daya luarbiasa sehingga ia berpotensi untuk mengetahui kebenaran sejati. para failasuf Muslim, terpengaruh oleh pandangan dari para bijaksana Yunani, khususnya Plato dan Plotinus, bahwa akal tidak hanya sebuah entitas metafisik yang berada dalam diri manusia, tetapi ada sebuah akal tunggal dan universal ( $a l$ - 'aql al-kullī) yang menggerakan semesta. Akal yang ada dalam diri manusia adalah akal partikular atau bagian terkecil yang juga mendapat pancaran emanasidari akal universal tersebut.

Kelompok Ismā'ìliyyah merupakan salah satu kelompok rasionalis yang meyakini bahwa kewajiban beragama tertinggi adalah pengetahuan dan pengetahuan tertinggi hanya didapat dengan iluminasi dari akal universal yang termanifestasi dalam diri Imam. ${ }^{11}$ Dalam doktrin Ismailiyah, yang dibawakan oleh Mū'ayyad Fid Dīn al-Shirazī dan oleh muridnya, Nāsir Khusraw, ${ }^{12}$ akal universal (al-'aql kullī) bersumber dari Allah dan akal universal dapat

${ }^{10}$ Imam Gazālī, Ringkasan Ihyā Ulūmuddīn, terj. Labib (Surabaya: Bintang Usaha Jaya, 2007), 21.

${ }^{11}$ Bernard Lewis, Assasin: Sejarah Sebuah Sekte Radikal dalam Islam, terj. Irfan Zakki Ibrahim (Yogykarta: Ircisod, 2018), 59.

${ }^{12}$ Nāsir Khusraw, The Book of Enlightement, terj. W. Ivanov (Bombay: Ismaili Society, 1949), 14-18. 
berhubungan dengan Allah tanpa perantara (selain akal universl, semua makhluk harus melalui medium untuk berhubungan dengan Tuhan). Dari akal universal, muncul jiwa universal (al-nafs al-kulliyyah) dan dari jiwa universal muncul materi universal (al-hayūlā al-kulliyyah). Akal memerankan peran penting dalam doktrin Ismā 'ìliyah karena akal universal adalah sumber dari semesta dan akal universal mewujud dalam diri para Imam $S y \bar{\imath}$ 'ah.

Sebagaimana yang sudah diterangkan diatas, konsep Ismā'īliyah meyakini bahwa tujuan manusia beragama adalah mencapai pengetahuan tertinggi dan agar manusia mendapat pengetahuan tersebut akal harus selalu diasah melalui ibadat, refleksi falsafi, dan mendengar wejangan para Imam. Sumber pengetahuan tertinggi Ismà 'îli adalah dengan jalan mendengar dan mengikuti ajaran Imam yang merupakan manifestasi akal universal. Karena itulah ajaran Ismā 'îliyah disebut juga sebagai tā'limiyyah. ${ }^{13}$

Akal dalam falsafat Ismā 'ìliyah, diri manusia mempunyai kemampuan akal dan juga nafsu. Akal bukan hanya sekedar alat dan sumber pengetahuan, akal adalah pembimbing manusia kejalan yang benar dan menuntun manusia kepada kebahagiaan. Sedangkan nafsu selalu menggiring manusia untuk mengalihkan dari kebaikan. Shahbuddin Shah, salah satu failasuf Ismā 'īli, mengajak agar manusia terus melakukan perenungan falsafi dan kontinyu pada jalan agama agar manusia tidak tersesat. ${ }^{14}$

Pembahasan Akal secara ontologis juga dijabarkan oleh al-Fārābī dan Ibn Sīnā mengenai teori emanasi ${ }^{15}$. Dalam teori al-Fārābī dan Ibn Sīnā, Allah digambarkan sebagai akal murni dan alam semesta ini muncul karena aktivitas berpikir Allah. ${ }^{16}$ Ketika Allah berpikir tentang dirinya (ta 'aqqul) sebagai sang maha pencipta, maka lahirlah akal pertama (Nous), ketika akal pertama berpikir tentang dirinya dan berpikir tentang Allah, maka lahirlah akal kedua. Akal kedua berpikir dirinya dan berpikir tentang Allah serta akal sebelumnya maka lahirlah akal ketiga, proses ini terus terjadi hingga akal ke 10, karena daya akal 10 sudah melemah dan jauh dari Tuhan, maka terciptalah materi dan unsurunsurnya sehingga terbentuklah bumi. ${ }^{17}$

${ }^{13}$ Hanna Al-Fakhuri dan Khalil Al-Jurr, Riwayat Filsafat Arab, terj. Irwan Kurniawan (Jakarta: Sadra Press, 2015), 208-211.

${ }^{14}$ Shahbuddin shah al-Husaini, Risala Dar Haqiqati Din, terj. W. Ivanov (Bombay: Ismaili Society, 1946), 11-12.

${ }^{15}$ Emanasi atau ematio, berarti suatu teori falsafat tentang kejadian penciptaan alam semesta yang terjadi melalui pancaran dari yang satu (Tuhan). Ide ini awalnya terinspirasi dari Plato kemudian dikembangkan oleh Plotinus dan diadopsi oleh para failasuf Muslim sebgagai teori yang menjelaskan tentang "bagaimana yang satu melahirkan yang banyak?"

16 Hadi Suprapto, "Al-Farabi dan Ibn Sina:Kajian Filsafat Emanasi dan Jiwa denganPendekatan Psikologi," Jurnal Al-Hadi 2, no. 2 (2017): 447.

17 Fuad Mahbub Siraj, "Kosmologi dalam Tinjauan Failasuf Islam," Jurnal Ilmu Ushuluddin 2, no. 2 (2014). 
Dari sini para failasuf Muslim menggambarkan bahwa akal bukan hanya sekedar alat berpikir dalam diri manusia, namun akal adalah suatu daya metafisis diluar manusia yang memiliki kekuasan luarbiasa. ${ }^{18}$ Dan akal universal memiliki hubungan dengan akal partikular yang ada dimiliki oleh manusia. alKindī dalam Rasa'il-nya menjelaskan relasi akal partikular dengan akal universal. al-Kindī membagi akal dalam 4 jenis,

"Akal itu ada empat macam, yang pertama ialah akal aktual abadi, kedua ialah akal yang ada secara potensial, yaitu yang mempunyai jiwa; ketiga ialah akal yang dalam jiwa beralih dari potensial ke aktual; keempat ialah akal yang kita namakan akal skunder. ${ }^{19}$ ",

Akal yang pertama ini adalah akal yang selalu dalam aktualitas yang terus menerus sadar akan apa yang terjadi dan akal ini diluar dari manusia. ${ }^{20}$ Sedangkan akal kedua adalah akal potensial yang "terpendam dalam jiwa". Akal kedua ini merujuk pada potensi dan kemampuan manusia untuk bertindak melakukan sesuatu. Sedangkan akal ketiga adalah transisi dari akal kedua ke akal keempat, dan akal keempat adalah akal yang sudah berwujud aktual dan menjadi kenyataan. ${ }^{21}$ Ketika akal yang selalu aktual memberikan ide-ide kepada jiwa manusia, ia disebut mufid (yang memberi), sedangkan jiwa yang mendapat pancaran ide-ide dari akal aktual disebut mustafid (yang terperoleh) sedangkan akal (ide-ide) yang menghubungkan antara akal aktual dan jiwa manusia disebut akal mustafād (akal perolehan) jika manusia telah mendapat akal mustafäd secara sempurna, maka ia akan menjadi insan al-kamil. ${ }^{22}$

Penjelasan para failasuf Muslim yang membahas akal secara ontologis mungkin sebagai bentuk pembelaan sekaligus perlawanan terhadap kaum tradisionalis yang kerap menyepelekan akal dan menganggap akal pikiran manusia itu lemah sehingga tak mampu menggapai kebenaran wahyu llahi. Para failasuf berusaha untuk mengumpulkan hujjah secara rasional bahwa akal bukan hanya mampu mengenal kebenaran, tetapi akal itu sendiri secara metafisis adalah sumber dari pengetahuan dan juga suatu wujud terpenting dalam proses penciptaan. Bahkan al-Fārābī lebih jauh mengatakan bahwa kenabian itu sendiri merupakan proses sempurnanya akal manusia dalam menerima informasi dari akal aktif. Seorang nabi bererti orang yang akalnya telah sampai pada akal

${ }^{18}$ Astuti Budi Handayani dan Suyadi, "Relevansi Konsep Akal Bertingkat Ibnu Sina dalam Menunjang Pendidikan Islam di Era Milenial," Jurnal Ta'dibuna 8, no. 2 (2019): 222240.

19 Rasa'il Alkindiyyah yang diterjemahkan oleh Nurcholish Madjid dalam buku Khazanah Intelektual Islam, lihat Nurcholish Madjid, Khazanah Intelektual Islam, 95.

${ }^{20}$ Havis Aravik dan Khois Amri, "Menguak Hal-hal Penting dalam Pemikiran Filsafat al-Kindi,” Jurnal Salam: Jurnal Sosial dan Budaya Syar-i 6, no. 2 (2019): 201.

${ }^{21}$ Tony Abboud, Al-Kindi: Perintis dunia Filosofi Arab, terj. Azimattinur Siregar (Jakarta: Muara, 2013), 69.

${ }^{22}$ Abdul Aziz Dahlan, Pemikiran Falsafi dalam Islam (Jakarta: Djambatan, 2003), 52. 
mustafād sehingga ia dapat menangkap ide-ide abstrak,dan ide-ide itu disebut wahyu. $^{23}$

\section{Akal dalam Perpektif Mutakallimūn dan Fuqaha}

Berbeda dari para failasuf yang mendudukan akal kedalam konsep ontologis dan mengangkat superioritas akal, para mutakallimūn dan ahli fiqh tidak begitu menyambut secara antusias konsep akal yang dijabarkan oleh para failasuf, mutakallimūn dan fuqaha dari kelompok ahl ra'yu memandang bahwa akal bukan fondasi dasar, tetapi hanya instrumen epistemologi dalam menggali kebenaran yang terdapat dalam wahyu dan juga menimbang baik-buruk realitas serta permasalahan di masyarakat.

Walau semua manusia memiliki akal, tidak semua manusia dengan akalnya langsung bisa berijtihad atau menalar konsep tentang Allah secara tepat, tetapi membutuhkan ilmu atau pengetahuan-pengetahuan sehingga akal mampu mengakumulasi pengetahuan menjadi suatu produk baru, entah itu sebagai produk hukum atau sebagai teori dalam masalah Usüuluddìn. Penulis sendiri belum menemukan kepercayaan kaum teolog rasional, yaitu Mu'tazilah, mengenai keyakini adanya akal aktif yang memberikan pancaran ide pada akal partikular yang ada dalam jiwa tiap individu. Namun mazhab $\mathrm{Mu}$ 'tazilah percaya bahwa secara potensi, akal manusia itu sama dan memiliki kemampuan yang sama. Akal tidak serta merta seperti anggapan kelompok platonik yang meyakini setiap pengetahuan telah tertampung didalamnya. Namun akal memberi respon terhadap kondisi atau fenomena disekelilingnya. Sehingga akal adalah entitas yang memiliki sensitifitas yang tinggi untuk menilai suatu fenomena empiris. Akal dalam pandangan mutakallimūn memiliki otoritas untuk penolakan (proskriptif) atau penentuan (prekriptif) atau afirmatif dan dismissif. ${ }^{24}$ Sehingga dalam pandangan $\mathrm{Mu}$ 'tazilah kemampuan akal mampu mengetahui adanya Tuhan, kewajiban untuk menyembah Tuhan, serta menentukan baik dan buruk. $^{25}$

Sedangkan para ahli fiqh rasional seperti golongan $\mathrm{Kufah}^{26}$ meyakini bahwa akal sangat dibutuhkan untuk menjawab masalah-masalah mendesak

${ }^{23}$ Ahmad Badwi, "Filsafat Al-Nafs, Filsafat Kenabian, Filsafat Madinah, Filsafat AlFadhillah dalam Pandangan Al-Farabi," Jurnal As-Shahabah 5, no. 2 (2019): 239.

${ }^{24}$ Wardani, Epistemologi Kalam Abad Pertengahan (Yogyakarta: LKIS, 2003), 90.

25 Harun Nasution, Teologi Islam: Aliran-Aliran, Sejarah, Analisa Perbandingan (Jakarta: UI Press, 2012), 82.

${ }^{26}$ Sebelum madzhab Abu Hanifah muncul, istilah yang digunakan para ulama masa itu adalah golongan Ahl kufah dan golongan ahl hijaz. Golongan kufah adalah orang yang menggunakan ra'yu atau akal dalam memutuskan perkara agama dan kuat dalam berspekulatif, sedangkan golongan ahl hijaz adalah kelompok yang memegang teguh tradisi hadits, fatwa sahabat, dan tradisi (amal) penduduk kota Madinah. 
yang tidak memiliki landasan syariat yang jelas dalam kitabullah. Sehingga akal menjadi tumpuan dalam ijtihad untuk menjawab persoalan-persoalan hukum. ${ }^{27}$

Alasan lain yang penulis tangkap mengapa para fuqaha Kufah lebih condong kepada nazhar wa ijtihad (refleksi dan penalaran) yang bersifat spekulatif, disebabkan karena kota Kufah atau negeri Iraq adalah kawasan metropolitan. Sebuah jalur perdagangan strategis tempat bertemunya bangsabangsa dan terjadinya silang budaya, sehingga hadits-hadits dan atsar yang tersebar di kota Kufah tidak mencukupi untuk menjawab problem baru. Produk fiqh mereka adalah qiyas dan istihsan ${ }^{28}, u r f^{29}$, dan qiy $\bar{a} s^{30}$ ketiganya adalah formulasi (sebuah metode fiqh) guna menjawab berbagai persoalan baru yang dihadapi.

Selain menangani problem-problem baru, akal tetap dibutuhkan dalam masalah hukum. M. Baqir Sadr, seorang Fuqaha mazhab Imamīyah, al-Idrāk al'Aqli (pemahaman akal) sangat dibutuhkan untuk meriset suatu masalah hukum. Sebab di lapangan, selalu ditemukan persoalan mana yang benar dan mana yang salah, mana yang baik dan mana yang lebih baik, mana yang dilarang dan mana yang diwajibkan. Untuk mengetahui persoalan diatas, maka akal dibutuhkan.

"suatu tindakan tidaklah mungkin dilarang dan diwajibkan pada waktu yang sama.. ia dibuktikan melalui akal, sebab akal memahami bahwa kewajiban dan larangan adalah dua kualitas atau sifat yang saling bertentangan, dan bahwa suatu entitas tunggal tidaklah mungkin (dapat) sekaligus memiliki dua kualitas atau sifat yang saling bertentangan",31

Disini dapat disimpulkan bahwa peran akal dalam kalam dan fiqh bagi kaum rasionalis sangat penting. Namun para mutakallimun dan fuqaha tidak serta merta mengikuti pendapat para failasuf tentang hakikat akal. Bagi mereka, akal hanya sebagai salah satu instrumen epistemologi atau metode untuk menafsirkan nash kitab suci, menyimpulkan mana yang baik dan buruk, serta sebagai pembenaran dari iman.

Salah satu fungsi akal bagi mutakallimūn adalah pembelaan (apologi) terhadap prinsip-prinsip agama, sedangkan bagi fuqaha, akal digunakan untuk menetapkan hukum syariat dan kemaslahatan sosial. Dalam hal ini pandangan

${ }^{27}$ Ibrahim, “Ajaran Islam Dalam Pandangan Harun Nasution” Jurnal Aqidah-ta 5, no. 2 (2019): 137.

${ }^{28}$ Istihsan adalah menganggap baik atau mencari yang baik. Atau meninggalkan hukum yang telah ditetapkan kepada hukum yang lainnya, pada suatu peristiwa atau kejadian yang ditetapkan berdasar dalil syara'.

${ }^{29}$ ' $U r f$ secara sederhana adalah budaya yang berkembang di masyarakat

30 Analogi sebagaimana ilmu logika, namun qiyas disandarkan pada hukum-hukum yang terdapat dalam Quran dan hadits

${ }^{31}$ Murtadha Muthahhari dan M. Baqir Sadr, Pengantar Ushul Fiqh dan Ushul Fiqh Perbandingan, 54. 
fuqaha dan Mutakallimūn lebih realistis ketimbang para filusuf yang agak "utopia" dalam memahami akal, yaitu mengejar kebenaran segala sesuatu.

\section{Akal Menurut Kaum Tradisional}

Kaum tradisional, dalam artian ahl hadīs, adalah kelompok orang-orang yang berpegang teguh pada teks al-Qur'an, sabda Nabi Muhammad, fatwa sahabat, dan kesepakatan para ulama salaf. Dalam masalah istinbat hukum mereka lebih mengacu pada atsar dan nusus. Sedangkan peluang penggunaan akal sangat keci dalam menggali masalah agama, bahkan yang lebih ekstrim diatara mereka melarang penggunaan akal dan bersandar pada teks lahir kitab suci dan juga teks sunnah Nabi yang terhimpun dalam kitab-kitab hadīits, contoh kelompok yang terakhir adalah kelompok $A k h b \bar{a} r \bar{\imath} .{ }^{32}$

Berbeda dengan para failasuf dan para ulama ahl ra'y, para ulama ahl hadīs begitu skeptis terhadap kemampuan akal dan juga penggunaan akal dalam agama (walaupun tidak seluruhnya menolak kemampuan akal). Mereka berdalil dengan sebuah riwayat mengenai bahayanya menggunakan akal,

Rasulallah bersabda: "Barangsiapa yang mengatakan Al-Quran dengan pendapatnya atau dengan apa yang tidak diketahuinya, maka hendaklah ia menempati tempat duduknya di neraka"

Bagi kelompok ahli hadits, menafsirkan al-Qur'an atau Sunnah dengan akal adalah haram, karena ra'yu adalah dugaan atau spekulasi, sedangkan spekulatif berarti prasangka yang dapat benar dan dapat salah, dengan begitu penafsiran Qur'an dengan akal tertolak. ${ }^{33}$ Ibn Jarīr at-Tabarī meriwayatkan hadits mengenai spekulasi akal: "Barangsiapa yang mengatakan dalam AlQuran dengan ra'yu-nya (pemikirannya) lalu dia benar, maka dia telah salah" Ibn Jarīr at-Tabarī mengatakan bahwa penggunaan akal atau $r a^{\prime} y u$ sama sekali tidak sah. Sebab ra'yu bersifat spekulatif tanpa didasari pemahaman dan dalil hujjah nash yang kuat. Spekulatif yang hadir dari pendapat pribadi (tanpa hujjah yang kuat) itu sama saja dengan perasangka kosong, walaupun benar tapi dimata Allah dia telah salah. ${ }^{34}$

Penolakan akal dan asumsi pemikiran ( $\left.r a^{\prime} y\right)$ ditegaskan oleh seorang ualam yang cukup ekstrim dalam hal ini yaitu Abu Utsman bin Sa 'īd ad-

${ }^{32}$ Lenni Lestari, "Epistemologi Hadits dalam Perspektif Syi’ah,” Jurnal Al-Bukhari 2, no. 1 (2019): 48.

${ }^{33}$ Muhammad Arsyad Nasution, "Pendekatan dalam Tafsir: Tafsir Bi Al Matsur, Tafsir Bi Al Ra yi, Tafsir Bi Al Isyari," Jurnal Yurisprudentia 4, no. 2 (2018): 156.

${ }^{34}$ Ibn Jarīr al-Ṭabarī, Tafsir al-Ṭabarī, terj. Ahsan Askan (Jakarta: Pustaka Azzam, 2007), 161. 
Dārimī, ia berkata: "Jika Al-Qur'an, hadits Rasulallah, dan Ijmak telah bergabung, maka tidak perlu kita menggunakan metode penafsiran lain",35

Pandangan Ini dikuatkan oleh al-Lâlakā' $\grave{l}$ yang berpendapat tentang keharusan (wujūb) manusia mengetahui Allah dan sifat-sifatnya berasal dari sam' (Al-Qur 'an dan Sunnah) bukan dari akal. Dia juga menyebut bahwa untuk urusan tauhid dan juga ibadah, akal tidak boleh digunakan, sebab ranah prinsip Ușùl dan ibadah yang menjadi rujukan utama adalah wahyu dan keputusan rasulnya.

al- Marīsī menegaskan terlarangnya akal dalam membahas ibadah dan akidah. Ia juga menuturkan jika terdapat sunnah atau riwayat yang menjelaskan suatu keajaban Tuhan, maka akal tidak boleh bermain "utak-atik" disana, laysa fi sunnah qiyās (tak ada qias dalam sunnah) contohnya tentang hadits yang menceritakan "hati manusia berada di dua jemari Allah" para ulama tradisional menjelaskan bahwa hadits ini tidak boleh di ta'wil dengan kekuasaan Allah. Tangan dalam bahasa Arab adalah tangan, dan tidak pernah para sahabat terdahulu menjelaskan tangan adalah kekuasaan. ${ }^{36}$

Penulis tidak menemukan bagaimana pandangan ulama tradisionalis mengenai akal dari sisi ontologis. Namun ulama tradisionalis berkeyakinan bahwa rasio manusia hanyalah kemampuan biasa manusia. bahkan akal itu sendiri bisa menyebabkan kesesatan karena berdasar dugaan. Abū Ḥāmid Muhammad al-Maqdisī justru malah berpendapat bahwa orang pertama yang menggunakan qias (qiyās) adalah Iblis. Dahulu Iblis berpikir bahwa ia adalah makhluk terbaik karena mengqiaskan bahwa api lebih baik kedudukannya ketimbang tanah. ${ }^{37}$ Secara tidak langsung, al-Maqdisī sangat skeptis terhadap peran akal dan berpandangan bahwa qiȳ̄s merupakan perbuatan dan sifat setan.

Ulama-ulama tradisional lainnya yang menolak peran akal dalam agama juga muncul dari kelompok Syī'ah. Mirza Muḥammad Amīn Astarābādī. Astarābādī adalah pelopor gerakan pemurnian dalam mazhab dan melarang akal pikiran manusia menggantikan kedudukan Qur 'an dan Sunnah (serta fatwa para Imam $S y \bar{\imath} ‘ a h$ ). Kelompok Mirza Astarābādī ini mendapat julukan Akhbārīyyah ${ }^{38}$

35 Binyamin Abrahamov, Ilmu Kalam: Tradisionalisme dan Rasionalisme dalam Teologi Islam, terj. Nuruddin Hidayat (Jakarta: Serambi, 2002), 21.

${ }^{36}$ Uqbatul Khoir Rambe, "Hadits Tematik Antropomorfisme," Jurnal Shahih 2, no. 1 (2019): 12 .

37 Binyamin Abrahamov, Ilmu Kalam: Tradisionalisme dan Rasionalisme dalam Teologi Islam, 157.

${ }^{38}$ Sedangkan lawan dari kaum Akhbārī adalah kaum Ușūli, kelompok Akhbārī menilai bahwa Qur 'an dan hadīs telah lengkap sempurna, sehingga aktivitas ijtihad tidak diperkenankan. Ijtihad bagi Astarābādī adalah otoritas mutlak Imam maksum, dan tidak diperkenankan manusia biasa berijtihad yang artinya mengambil alih hak otoritatif Imam. Sedangkan kelompok Ușūli meyakini bahwa akal adalah hujjah dan alat yang dibutuhkan dalam membuktikan kebenaran Wahyu ilahi. Ketika Imam ke duabelas mengalami masa keghaiban, 
atau orang yang menerima khabār Quran dan hadis serta menolak keberadaan Ușūl fiqh sebab menurut Astarābādī, Ușūl fìqh adalah celah bagi akal untuk masuk kedalam ranah syariah dan merecokinya.

Astarābādī membagi pengetahuan menjadi dua jenis. Pertama adalah pengetahuan dari pengamatan indera dan pembuktian eksperimental. Dan yang kedua adalah pengetahuan yang berasal daria asumsi-asumsi rasio. Dalam masalah ilmu pengetahuan umum, Asatarābādī mengakui kebenaran eksperimen inderawi, karena itu dibuktikan secara nyata. Asatarābādī juga menerima asumsi-asumsi deduktif dari rasio manusia, selama asumsi tersebut berkaitan dengan hal-hal yang dapat diindera. Namun dalam hal agama yang merupakan objek yang non inderawi, Astarābādī menolak asumsi akal, sebab agama adalah masalah iman dan Tuhan bersifat metafisik. Asumsi dan opini subjektif tidak berlaku dalam hal agama, kecuali melalui metode yang sudah pasti kebenarannya, yaitu wahyu ilahi, sabda nabi dan imam ahl bayt. Astarābādī mengutip sabda Imam Ja'far as-Sadiq, "tidak ada sesuatu yang jauh dari jangkauan akal manusia kecuali al-Qur 'an" dengan berlandaskan ucapan imam ahl bayt, Asatarābādī dan kelompok tradisional akhbārīyyah ingin meneguhkan pandangan mereka bahwa akal tidak akan mampu menjangkau kebenaran kitab suci. $^{39}$

Walaupun kaum tradisional Islam mengecilkan akal sebagai alat untuk menggali kebenaran, namun bukan berarti Ulama tradisionalis seluruhnya menolak kemampuan akal. Imam Syāfi'‘̄̄, adalah contoh ulama ahl hadīs yang meyakini bahwa akal merupakan salah satu alat untuk memhami agama dan modal utama dalam istibāth hukum, Syāfi'‘̄ kemudian memrumuskan dan membakukan metode qiyās dalam kitabnya Ar-Risālah. Ini berarti kelompok tradisionalis itu sendiri tidak seluruhnya menolak kemampuan akal.

Ibn Hazm al-Andalusi seorang ulama tradisional bermazhab Zahiriyyah yang berdomisili di Spanyol (Andalusia). ia mengapresiasi kemampuan akal sebagai alat untuk mengupas kebatilan dan menyibak kebenaran. Akal menurut Ibn Ḥazm lebih tinggi dari indera. Sebab, andaikata akal itu tidak ada maka kita tidak akan mengetahui sesuatu yang hilang dari indera kita dan kita tidak tahu mengenai kebenaran adanya Allah. Walaupun harus diakui bahwa dalm metode istimbāt hukum, Ibn Hazm menolak penggunaan ra'yu namun metode deduksi dalam ushul fiqhnya, yaitu al-dalil sangat mirip dengan konsep ilmu logika $(\text { Mantiq })^{40}$

maka para ulama dan terpelajar wajib berijtihad untuk menjaga agama Islam dimasa kekosongan hingga sang Imam kembali ke dunia.

${ }^{39}$ Hasan Yusufian dan Ahmad Husain Sharifi, Akal dan Wahyu, terj. Ammar Fauzi Heryadi (Jakarta: Sadra press, 2011), 177.

${ }^{40}$ Taufiqul Hadi, "Fikih dan Metode Istimbat Ibn Hazm,” Jurnal Syarah 8, no. (2019): 118. 
Ibn Taymīyyah dan Najm al-Dīn al-Thūfi adalah imam dari mazhab Hanābilah (tradisional) yang cukup liberal. Dalam mengemukakan masalah akal dan wahyu, Ibn Taymīyyah berpendapat bahwa menerima setiap yang datang dari pemahaman wahyu, pasti tidak bertentangan dengan akal. Sebab wahyu dari Allah dan akal adalah salah satu dari makhluk Allah, tentu keduanya tak mungkin bertentangan. ${ }^{41}$

Walau hingga saat ini Ibn Taymīyyah yang terkenal sebagai tokoh kaum tradisionalis yang paling gigih mencela mutakallimūn dan failasuf, namun dalam persoalan antara akal dan wahyu, Ibn Taymīyyah memberikat apresiasi cukup tinggi kepada akal. Najm al-Dīn al-Thūfi malah berpandangan lebih liberal lagi terhadap akal.

Ia merumuskan konsep maslahah yang merupakan salah satu prinsip ilmu Ușūl fiqh. Sebagai seorang penganut Hanābilah, teori al-Thūfi tentang maslahat cukup liberal dari keyakinan para ulama tradisionalis yang semazhab dengannya. Ia mengatakan bahwa maslahat adalah mu'tabar bi al ra'yi (keputusan yang mu tabar menurut akal). karena itu, jika terdapat pertentangan antara maslahah dengan nash, maka maslahat yang lebih didahulukan ketimbang nash $^{42}$. Pandangan al-Thūfi (sebagai seorang ulama tradisionalis) yang sangat memberikan porsi yang besar terhadap akal, merupakan bantahan bahwa seluruh kelompok ahli hadits menolak penggunaan akal. Konsep dan fungsi akal menurut ulama tradisional berbeda dari failasuf dan Mutakallimūn, akal bagi ulama tradisional juga dianggap penting namun karena mereka memegang teguh dan meyakini wahyu Allah dan juga tradisi ulama salaf terdahulu adalah hujjah terpenting dalam agama, karena itulah para ulama tradisionalis cenderung menyepelekan akal atau memposisikan akal dibawah Qur 'an bahkan tradisi ulama terdahulu.

\section{Rasionalisme dan Tradisionalisme dalam Pertimbangan}

Perdebatan antara kaum rasional dan tradisional berlangsung dengan cukup panas diawal abad ke 2-3 hijriyah kedua kubu saling bantah dan melempar argumen masing-masing. Kaum rasional seperti Syaikh Ibrāhīm alNaz̧āām mengkritik kaum ahl ḥadīs sebagai orang-orang bodoh yang tidak menggunakan akalnya. Bahkan al-Naz̧āam (dikutip oleh Ibn Qutaybah) mencontohkan Abdurrahman al- A'masy, seorang pemuka perawi hadits di kota Kufah dianggap sebagai orang aneh dan kurang waras oleh a- Naz̧āām. Sebaliknya, kaum tradisional juga menuduh kaum rasional sebagai orang-orang

41 Izuddin Washil dan Ahmad Khoirul Fatta, "Pemikiran Ibn Taimiyah tentang Syariah Sebagai Tujuan Tasawuf," Jurnal Teosofi 7, no. 2 (2017): 324.

42 https://islam.nu.or.id/post/read/101675/konsep-supremasi-maslahat-dalampemikiran-najmuddin-at-thufi diakses 29/07/2019 
zindiq karena telah memasukan ilmu Yunani, yaitu logika kedalam ilmu agama, sehingga Ibn Șalāḥ mengharamkan ilmu logika atau manțiq secara mutlak, sehingga muncul aforisma, man tamanthaqa tazandaqa (barangsiapa yang berlogika, maka ia telah zindiq) $)^{43}$.

Terjadi pertentangan sengit antara kaum rasional dan tradisional sebagaimana yang penulis paparkan diatas sekilas menggiring opini bahwa kaum rasional melebihkan akal di atas wahyu dan kaum tradisional terlalu fanatik menggunakan dalil wahyu tanpa memperdulikan akal. Anggapan "pukul rata" ini sama sekali keliru. Sumber literatur Islam yang masih dapat kita lacak sampai saat ini, baik dari kelompok tadisional dan rasional sama-sama mengakui otoritas wahyu dan sama-sama mengakui kekuatan akal dalam memutuskan setiap perkara. Pertentangan antara ahl ray' dan ahl hadīs hanya terjadi dimasa awal Islam. tepatnya kurun abad ke-2 hijriyah ketika agama Islam mulai tersebar keseluruh dunia dan menjangkau berbagai suku dan elemen masyarakat. Agama Islam sebagai agama baru diantara agama, kepercayaan dan aliran falsafat yang berada di jazirah Arab, berusaha menemukan bentuknya dan merumuskan prinsip-prinsip dogma agama (Ușūluddīn)

Perdebatan mengenai peran akal dalam Islam merupakan perdebatan yang bersifat epistemologis di kalangan ulama-ulama Islam awal, dari perbedaan pandangan di kalangan ulama mengenai fungsi akal dalam agama, kemudian menciptakan dua aliran besar yaitu rasionalisme ( $\left.a h l r a^{\prime} y\right)$ dan tradisionalisme ( ahl ḥadīs) baik dalam bidang kalām atau fiqh. Kelompok tradisional berpusat di kawasan Hijaz disebabkan kawasan tersebut berlimpah sumber-sumber riwayat baik atsar para Sahabat maupun hadīs dari Nabi Muḥammad, sehingga para ulama tradisionalis mencukupkan diri para riwayat nash dalam penetapan dogma dan hukum Islam. Sedangkan kaum rasional muncul di kawasan Kufah dan Basrah, sebuah kawasan metropolitan dan cukup beradab. Kekurangan riwayat dari hadìs nabi dan kabar dari para sahabat nabi membuat para ulama di Kufah berpegang pada akal mereka, sehingga baik dalam perumusan dogma dan hukum Islam, para ulama Kufah berpijak pada akal (tanpa mengesampingkan alQur'an dan Sunnah) di kota Kufah ini lebih jauh para mutakallimūn mengembangkan pemikiran falsafi serta secara terbuka menerima falsafat Yunani dan mengintegrasikannya dengan agama Islam.

Selain karena masalah geografis sebagaimana dijelaskan diatas, persaingan antara ulama kota Hijaz dan kota Kufah membuat perdebatan mengenai fungsi akal semakin menarik. Para ulama di kedua kota tersebut masing-masing memiliki motif politis yaitu ingin menjadikan kotanya menjadi pusat peradaban Islam. persaingan rasial antara Arab dan Ajam (non Arab) turut menambah runcing persaingan, ini dilukiskan dalam suatu cerita, dimana

${ }^{43}$ Saidd Hossein Nasr dan Oliver Leaman, Ensiklopedia Tematis Filsafat Islam, Jilid 1, terj. Tim penerjemah Mizan (Bandung: Mizan, 2003), 130. 
Hiisyām bin Abd Mālik hampir menghukum Ațā ibn Abī Rabbah karena banyaknya fuqaha disetiap kota yang berstatus non Arab. ${ }^{44}$ Motif politik dan tendensi rasial ini turut menambah perselisihan para ulama tentang status akal dalam agama. Para ulama Hijaz menolak akal untuk meruntuhkan fondasi keilmuan ulama Kufah. Sebaliknya, ulama Kufah mengkritik ulama Hijaz yang tidak menggunakan akal untuk memahami agama (tāafaqquh fiddīn) disini kita dapat simpulkan bahwa baik para ulama Hijaz dan Kufah pada masa awal, sama-sama mengakui otoritas wahyu, namun mereka berbeda pandangan soal fungsi akal. Tidak benar bahwa kelompok Mu'tazilah dan ulama Kufah lainnya menggunggulkan akal daripada wahyu, baik para mutakallimūn, fuqaha Kufah, dan failasuf Muslim ${ }^{45}$ mengakui otoritas wahyu serta kebenaran wahyu.

\section{Sisi Rasional dari kaum Tradisional}

Penggunaan akal dalam Islam mulai longgar pada abad ke awal $3 \mathrm{H}$. Ketika batas geografis kubu Hijaz dan kubu Kufah hilang akibat terjadinya rihlah atau perjalanan para pelajar untuk menuntut ilmu ke kota-kota besar. Imam Syāfi'ì yang pernah belajar dengan ulama Kufah dan Hijaz, kemudian mensintesakan antara nash dan naql. Syāfi' '̄ adalah tokoh tradisional yang mempelopori ilmu ușūl fiqh dalam kitabnya al-Risālah, dalam kitab tersebut, akal menjadi salah satu metode penting dalam istibath hukum, peran akal dimanifestasikan dalam metode qiyās. Lebih jauh lagi Ibn Taimiyah adalah salah satu tokoh ulama tradisional yang menerima akal sebagai salah satu asas terpenting Islam. bagi Ibn Taymiyah, tidak mungkin akal bertentangan dengan wahyu, sebab akal adalah penguat kebenaran dari wahyu.

Dalam bidang teologi, Imam Abū Ḥasan al-Asy'arī dan Abū Manșūr alMāturīdī berusaha memasukan unsur rasionalitas dalam teologi kalām Sunni. Sebelum kedua tokoh tersebut, kalām Sunni merupakan kumpulan doktrindoktrin ajaran yang tidak memiliki basis aqli yang kuat didalamnya, sebagaimana tertuang dalam kitab Aqidah Tahawiyyah, setelah munculnya Abū Ḥasan al-Asy'arī dan al-Bāqillān̄̄, teologi Mazhab Sunni mulai menggunakan kesimpulan deduktif ala logika aristotelian dan metode jadal. Doktrin Kasb ${ }^{46}$

${ }^{44}$ Tariq Suwaidan, Biografi Imam Abu Hanifah, terj. Tufik Damas dan Zaenal Arifin (Jakarta: Zaman, 2011), 25.

${ }^{45}$ Banyak para tokoh pengkaji falsafat Islam baik Harun Nasution hingga orientalis seperti JWM Bakker meyakini bahwa failasuf Muslim, Abū Bakr Muhammad b. Zakariyyā alRazī sebagai penolak wahyu Al- Qur 'an. Namun pandangan ini justru lahir dari para penentang al-Razī sehingga bisa dikatakan kurang objektif, ditambah lagi kita tidak bisa memverifikasi kebenarannya karena kitab-kitab al-Razī telah hilang, namun dalam biografinya, Chahar Maqala, ia menulis bahwa al-Razī mengutip ayat al- Qur 'an surah ke 2 ayat 192-195 ketika berdialog dengan para tokoh dinasti Samaniyyah. Ini menunjukan bahwa al-Razī masih meyakini Islam dan wahyu.

${ }^{46}$ Kasb atau akuisisi dalam kamus teologi Islam berarti adanya kemampuan manusia dan kuasa Tuhan dalam perbuatan manusia. Tuhan memberi daya kuasa bagi manusia untuk mempunyai otoritas dalam perbuatannya. Kasb sering dianalogikan dengan orang dewasa dan 
dalam kalām Asy'arīyyah merupakan contoh bagaimana ulama Ahlussunah mencoba merasionalkan konsep perbuatan manusia dan takdir yang tercantum dalam al-Qur'an dan Hadits.

\section{Tradisi dalam pandangan Kaum Rasional}

Fitnah dari beberapa kelompok tradisional adalah pengebirian wahyu oleh kelompok mutakallimūn dan failasuf, pendapat ini sangat keliru dan salah. Jika kita melihat kitab-kitab para filusuf Muslim dan juga ahli kalām, mereka selalu memposisikan dirinya sebagai pembela wahyu dan Al-Qur 'an. Wahyu sangat tinggi perannya sebagai sumber ilmu dan informasi wahyu harus dipercaya kebenarannya. al-Fārābī bahkan berpendapat bahwa para nabi adalah manusia sempurna karena mendapat limpahan langsung ilmu pengetahuan dari aqal fa'al atau akal kesepuluh yang berarti Jibril. Dari sini sudah terlihat bahwa para failasuf bukanlah ingin melangkahi wahyu, namun memperjelas dan membuktikan kebenaran wahyu secara demonstratif. Memang secara sekilas teori-teori falsafi tidak terdapat dalam teks kitab suci, namun bukan berarti bersebrangan. Ibn Rusyd adalah tokoh failasuf sekaligus fuqaha yang berusaha mendamaikan akal dan wahyu. Ibn Rusyd membuktikan walau bahwa kebenaran demonstratif yang digunakan para failasuf, sama dengan kebenaran wahyu, contohnya mengenai teori Thales bahwa dunia bermula dari air. Menurut Ibn Rusyd, teori Thales ini berkesesuaian dengan Al-Qur 'an 21: 30: "Dan dari air Kami jadikan segala sesuatu..."

Menurut Ibn Rusyd dan Ibn Sīnā, akal berfungsi untuk menta'wilkan teksteks kitab suci, tujuannyan adalah untuk mengetahui hakikat dari pesan-pesan esoterik al-Qur 'an. al-Qur'an yang merupakan mukjizat dari Allah akan terasa sempit jika hanya diambil penafsiran tunggal, yaitu jika hanya menafsirkan dengan metode bi al-matsur dan dipahami secara lahiriah teksnya saja. Menurut Ibn Sīnā, al-Qur'an memiliki makna lahir dan makna batin. Tugas para filusuf adalah menggali makna batin al-Qur'an dengan akalnya agar tersibak hakikat yang sebenarnya.

Dalam masalah Hadits, kelompok rasional tidak menolak hadīs nabi dan bukan kelompok inkar sunnah. Mereka hanya selektif dalam memilah riwayat dan menguji keshahihan suatu khabar dengan akal pikiran. Kelompok Rasionalis (ahl ra'y) dari golongan $\mathrm{Mu}$ 'tazilah sangat berhati-hati dalam menerima hadits. Suatu ketika Bakr ibn Ḥamdāni bertanya pada Amr ibn Ubaid mengenai hukum potong tangan, apakah seorang pencuri akan terbebas dari hukum potong tangan jika si korban memaafkan? Amr ibn Ubaid menjelaskan bahwa (sesuai maslahat) tidak ada seorangpun yang mampu membatalkan hukuman kecuali penguasa. Kemudian Bakr ibn Hạdāni meriwayatkan suatu Hadits yang

anak kecil yang mengangkat batu besar. Orang dewasa diibaratkan sebagai Tuhan dan anak kecil adalah manusia. kesimpulannya dalam tiap perbuatan manusia ada campur tangan Tuhan. 
bertentangan dengan fatwa Amr ibn Ubaid, lalu Amr langsung menyuruh Bakr b. Hamdāni bersumpah atas nama Allah, bahwa ia benar-benar yakin keotentikan Hadits tersebut, namun Bakr menolak bersumpah dan tidak berani mengatakan riwayat tersebut otentik dari nabi. Kisah ini menunjukan bahwa golongan $\mathrm{Mu}$ 'tazilah amat berhati-hati dalam menerima riwayat hadīs, khususnya dengan Hadits-hadits yang dianggap bertentangan dengan akal sehat. ${ }^{47}$

Melihat perbandingan diatas, kita bisa memahami bahwa kelompok rasional dan tradisional memiliki perbedaan dalam memandang fungsi akal, walaupun pada akhirnya kelompok tradisional mengakui peran dan fungsi akal, namun akal bagi kaum tradisional hanyalah alat semana yang bisa salah dan kekurangan, wahyu hadir sebagai penyempurna akal manusia. Sebaliknya kaum rasionalis tetap mengakui otoritas wahyu sebagai sumber primer agama, namun akal sangat dibutuhkan untuk memahami wahyu. Kedua aliran ini lahir dari perkembangan sejarah, yaitu ketika agama Islam tengah mengambil bentuk sebagai agama yang mapan. Serangan dari kaum ateis, Kristen, dan Yahudi, memaksa para ulama untuk merumuskan dan membakukan prinsip dasar dan pedoman dalam menetapkan hukum. Para ulama Kufah yang secara face to face berhadapan dengan "musuh-musuh" Islam, berusaha menguatkan agama Islam dengan menggunakan senjata akal sehat. Akal menjadi lebih dominan digunakan oleh ulama Kufah dan kemudian membentuk kelompok rasionalisme Islam. sedangkan ulama Hijaz yang kondisi masyarakatnya relatif stabil dan tidak terlalu majemuk seperti di Kufah, tidak terlalu dipusingkan oleh hantaman argumentasi dari "musuh-musuh" Islam, sehingga para ulama Hijaz tidak dipersoalkan dengan urusan rumit seperti di Kufah dan Basra, ini yang membuat mereka tetap berpegang pada tradisi dan sunnah nabi dalam menetapkan prinsip agama dan hukum tanpa mementingkan peran akal. Namun ketika suasana kian kompleks dan masyarakat Islam semakin berkembang, kaum tradisional mau tak mau harus menerima akal sebagai sumber epistemologis mereka dalam memutuskan masalah agama dan juga menjadikan akal sebagai senjata untuk menangkis argumentasi kaum ateis dan ahl al-bid'ah, termasuk membantah argumentasi dari kelompok rasionalis yang menjadi rivalnya.

\section{Kesimpulan}

Polemik akal dalam Islam lahir pasca wafatnya Rasulallah. Ketika Rasulallah dan para sahabat utama masih hidup, umat Islam senantiasa mengikuti petunjuk nabi dan fatwa para sahabat. Namun ketika agama Islam mulai melebarkan sayap-sayapnya kebelahan dunia lain. Maka Islam bersentuhan dengan beraneka ragam pemikiran dan juga beraneka masalah-

47 Joesoef Sou'yb, Peranan Aliran Iktizal dalam Perkembangan Alam Pikiran Islam (Jakarta: Alhusna, 1982), 116. 
masalah baru. Karena banyak masalah tidak dibahas secara rinci dalam alQur'an serta kabar dari rasul dan sahabat, akhirnya mau tak mau para ulama berijtihad menggunakan akal mereka untuk memecahkan masalah dan mencari solusi. Akal kemudian digunakan pula untuk menafsirkan al-Qur'an dan juga menyusun prinsip agama (Ușüluddìn) penggunaan akal oleh para teolog, fuqaha, dan juga oleh para filusuf, dianggap oleh para ulama yang tetap mempertahankan tradisi periwayatan sebagai bentuk 'kebablasan' pada awal abad kedua hijriyah, antara golongan rasional (ahl ra'y) dan tradisional (ahl hadīs) terdapat perselisihan dan polemik yang cukup kreatif mengenai fungsi dan peran akal. Bagi para filusuf dan mutakallimūn akal sangat berperan besar dalam agama dan pencarian kebenaran, bahkan para filusuf menjadikan akal sebagai fundamen atai sumber primer bagi pengetahuan dan meyakini adanya akal universal yang gaib dan menggerakan dunia. Sedangkan para ulama tradisionalis seperti mufassīr, fuqaha, dan muhaddīìūn hanya menganggap akal sebagai sumber skunder dan alat dalam memahami wahyu ilahi atau agama. Perselisihan mengenai akal dan wahyu ini kemudian mereda di abad-abad setelahnya, yaitu ketika Imam Syāfi'ī menulis kitab al-Risālah yang menjadkan metode akal (qiyās) sebagai metode resmi. Gagasan Ibn Rusyd dan juga Ibn Taymīyyah dalam mendamaikan akal dan wahyu, membuat pertentangan antara golongan rasional dan tradisional mulai mereda, walaupun hingga hari ini perdebatan mengenai peran akal dalam Islam masih kerap menjadi perdebatan, namun perdebatan tersebut tidak seramai masa lalau.

\section{Daftar Pustaka}

Abboud, Tony. Al-Kindi: Perintis dunia Filosofi Arab. Terj. Azimattinur Siregar. Jakarta: Muara, 2013.

Abdullah, Sulaiman. Dinamika Qiyas dalam Pembaharuan Hukum Islam. Jakarta: Pedoman Ilmu Jaya, 1996.

Abrahamov, Binyamin. Ilmu Kalam: Tradisionalisme dan Rasionalisme dalam Teologi Islam. Terj. Nuruddin Hidayat. Jakarta: Serambi, 2002.

Aravik, Havis, dan Khois Amri. "Menguak Hal-hal Penting dalam Pemikiran Filsafat al-Kindi." Jurnal Salam 6, no. 2 (2019).

Badwi, Ahmad. "Filsafat Al-Nafs, Filsafat Kenabian, Filsafat Madinah, Filsafat Al-Fadhillah dalam Pandangan Al-Farabi." Jurnal As-Shahabah 5, no. 2 (2019).

Dahlan, Abdul Aziz. Pemikiran Falsafi dalam Islam. Jakarta: Djambatan, 2003. 
Fakhuri, Hanna dan Khalil Al-Jurr. Riwayat Filsafat Arab. Terj. Irwan Kurniawan. Jakarta: Sadra Press, 2015.

Al-Ghazali. Ringkasan Ihya Ulumuddin. Terj. Labib. Surabaya: Bintang Usaha Jaya, 2007.

Hadi, Taufiqul. "Fikih dan Metode Istimbat Ibn Hazm." Jurnal Syarah 8, no. 2 (2019).

Handayani, Astuti Budi, dan Suyadi. "Relevansi Konsep Akal Bertingkat Ibnu Sina dalam Menunjang Pendidikan Islam di Era Milenial." Jurnal Ta'dibuna 8, no. 2 (2019).

al-Husaini, Shahbuddin shah. Risala Dar Haqiqati Din. Terj. W. Ivanov. Bombay: Ismaili Society, 1946.

Ibrahim. "Ajaran Islam Dalam Pandangan Harun Nasution.” Jurnal Aqidah-ta 5, no. 2 (2019).

Khusraw, Nasir. The Book of Enlightement. Terj. W. Ivanov. Bombay: Ismaili Society, 1949.

Lestari, Lenni. "Epistemologi Hadits dalam Perspektif Syi'ah.” Jurnal AlBukhari 2, no. 1 (2019).

Lewis, Bernard. Assasin: Sejarah Sebuah Sekte Radikal dalam Islam. Terj. Irfan Zakki Ibrahim. Yogykarta: Ircisod, 2018.

Madjid, Nurcholish. Khazanah Intelektual Islam. Jakarta: Bulan Bintang, 1984.

Muțahhari, Murtaḍa dan Muhammad Baqir Șadr. Pengantar Ushul Fiqh dan Ushul Fiqh Perbandingan. Terj. Satrio Pinandito dan Ahsin Muhammad. Jakarta: Pustaka Hidayah, 1993.

Nasr, Sayyd Hossein dan Oliver Leaman. Ensiklopedia Tematis Filsafat Islam. Terj. Tim penerjemah Mizan. Bandung: Mizan, 2003.

Nasution, Harun. Akal dan Wahyu dalam Islam. Jakarta: UI Press, 2011.

Nasution, Harun. Teologi Islam: Aliran-Aliran, Sejarah, Analisa Perbandingan. Jakarta: UI Press, 2012.

Nasution, Muhammad Arsyad. "Pendekatan dalam Tafsir: Tafsir Bi Al Matsur, Tafsir Bi Al Ra`yi, Tafsir Bi Al Isyari.” Jurnal Yurisprudentia 4, no. 2 (2018). 
Rambe, Uqbatul Khoir. "Hadits Tematik Antropomorfisme." Jurnal Shahih ,2 no. 1 (2019).

Rukmana, Aan. "Kedudukan Akal dalam al-Qur'an dan al-Hadis." Jurnal Mumtāz 1, no. 1 (2017).

Setiawan, M. Arif, dan Melvien Zainul Asyiqien, "Urgensi Akal Menurut Al Qur'an dan Implikasinya Dalam Mencapai Tujuan Pendidikan Islam." Jurnal Intelektual 9, no. 1 (2019).

Shiraj, Fuad Mahbub. "Kosmologi dalam Tinjauan Failasuf Islam.” Jurnal Ilmu Ushuluddin 2, no. 2 (2014).

Sou'yb, Joesoef. Peranan Aliran Iktizal dalam Perkembangan Alam Pikiran Islam. Jakarta: Alhusna, 1982.

Suprapto, Hadi. "Al-Farabi dan Ibn Sina:Kajian Filsafat Emanasi dan Jiwa denganPendekatan Psikologi.” Jurnal Al-Hadi 2, no. 2 (2017).

Suwaidan, Tariq. Biografi Imam Abu Hanifah. Terj. Tufik Damas dan Zaenal Arifin. Jakarta: Zaman, 2011.

al-Ṭabārī, Ibn Jarir. Tafsir al- Tabārī. Terj. Ahsan Askan. Jakarta: Pustaka Azzam, 2007.

Takdir, Mohammad. "Membumikan Fiqh Antroposentris: Paradigma Baru Pengembangan Hukum Islam yang Progresif." Jurnal Ahkam 7, no. 1 (2019).

Yusufian, Hasan dan Ahmad Husain Sharifi. Akal dan Wahyu. Terj. Ammar Fauzi Heryadi. Jakarta: Sadra press, 2011.

Wardani. Epistemologi Kalam Abad Pertengahan. Yogyakarta: LKIS, 2003.

Washil Izuddin, dan Ahmad Khoirul Fatta. "Pemikiran Ibn Taimiyah tentang Syariah Sebagai Tujuan Tasawuf.” Jurnal Teosofi 7, no. 2 (2017). 